\title{
3. Exile as Social Renewal: Theodor Herzl, Max Nordau
}

Along with the two most general forms of exile already discussed, turning inward and mere wandering, stands a very concrete type of exile-the concept of exile as a social renewal in the form of Zionism, a Jewish program aimed at escaping Europe's hopelessness, lack of values, and antisemitism by creating a free Jewish society in an entirely different geographical area, a homeland where Jews could truly realize themselves without fear, limitations, poverty, killing, and humiliation. This version of the concept of exile is the opposite of the aesthetic one and turning within. It is an outgrowth of the wandering, or its correction or continuance, which is based on a hope that it is possible to end exile permanently. Uri Zilbersheid suggests that Zionism is a multidimensional Jewish revival, and not merely a political matter. ${ }^{18}$

The personalities of certain thinkers stand out, notably those of Theodor Herzl (b. 1860 in Pest, d. 1904 in Reichenau an der Rax), author of The Jewish State (1895) and Max Nordau (b. 1849 in Pest, d. 1923 in Paris), author of The Conventional Lies of Our Civilization (1883) and Degeneration (1892), both born in Budapest and later moving to Vienna and Paris.They were the co-founders of the World Zionist Organization (1897) and co-creators of modern Zionism.

Zionism as an idea, then, has existed since the end of the nineteenth century, yet only certain layers of the Jewish population were originally able to identify with it and save their lives through it. Zionism represented a voluntary, chosen exile, a journey to

18 Uri Zilbersheid, "The Utopia of Theodor Herzl," Israel Studies 9, no. 2 (2004): 80. 
a faraway country, based on what seemed to some a utopian idea. While it has saved many lives in its time, it has not brought substantial peace for Jews even one hundred twenty years later. It has given birth to new manifestations of antisemitism around the world. Both Herzl and Nordau came to it after unsuccessfully trying to implement the idea of Jewish emancipation and assimilation and witnessing the mass rallies in Paris following the Dreyfus treason trial (1894), during which many chanted "Death to the Jews!" in the streets. This was especially significant, as France was often seen as the model of the modern, enlightened state-after all, it had emancipated the Jews in the aftermath of the revolution. The country established them as equal citizens to Frenchmen. Napoleon overrode old laws restricting Jews to ghettos, lifted laws banning Jews' right to own property and engage in certain professions. Judaism, in fact, became one of the official religions in France. In short, although emancipation and equality were written into the statute books of Europe, antisemitism was still alive in popular social consciousness, with the exception of Britain-likely due to its Protestantism, fundamental liberalism, lower Jewish population, and suspicion of Catholicism.

It was then that Herzl and Nordau conceived of the idea that Jews must leave Europe and found their own state. Herzl was probably even more influenced by the rise to power of the antisemite Karl Lueger in Vienna in 1895. It was then that he stopped believing that antisemitism could ever be eradicated or cured. Europe is, after all, chiefly Christian, and the religion's representatives from its beginnings have accused Jews of deicide.

Herzl made unsuccessful political and diplomatic efforts to secure some land where Jews could settle. He put in writing a detailed and masterful plan for the organization of the future democratic Jewish nation-state. It was to be a progressive, multilingual democracy, where essentially all would be taken care of. It would be a state that would even benefit European Christians, who would move into positions vacated by emigrating Jews and secure formerly Jewish property at very advantageous prices. The welfare state and the subsequent stateless society that Herzl proposed testify, according to Zilbersheid, "to his deep connection with the utopian 
tradition." ${ }^{19}$ Herzel's vision drew on Western cosmopolitanism rather than the Eastern European nation-oriented Zionism proposed by Ahad Ha'am, who "saw no point in any political solution that was divorced from a national solution." 20

Herzl's daughter died in the concentration camp Theresienstadt with her husband in 1943. Upon learning of his parents' fate, his grandchild, who was sent to England in 1935, where he became a captain in the British army, committed suicide by jumping from the Massachusetts Avenue Bridge in Washington, DC in 1946.

Nordau was central to the eleven World Zionist Congresses, which played a vital part in shaping what Zionism would become. As a critic of the West, he acutely characterized the European finde-siècle as an illness caused by degeneration and hysteria. In this respect, Nordau was an anti-aesthetic thinker who did not understand and appreciate the artistic innovations of his time. He was, though, a great supporter of Theodor Herzl's approach to Zionism.

His book Die konventionellen Lügen der Kulturmenschheit (1883) attacks all aspects of civilization - religion, monarchy, aristocracy, politics, economics, marriage, and so on, as lies that trap people and make them live inauthentic and embittered lives. Austrian official decree may have condemned the book, but Die konventionellen Lügen der Kulturmenschheit prophesied the disaster to come. Nordau believed in emigration as a solution to survival itself, as well as a solution to the economic problems associated with industrial society. In his attitudes toward art and women he is, however, extremely narrow-minded and moralistic.

Both Herzl and Nordau were attacked for ignoring Jewish spiritual values. Their idea was to build a tolerant secular society in Israel, escape the industrialization of Europe, and return to their historically native soil. Eastern Jews, more in touch with Jewish spiritual values, opposed this. Spirituality-occultism, magic,

19 Ibid.: 81.

20 Yossi Goldstein, “Eastern Jews vs. Western Jews: The Ahad Ha'amHerzl Dispute and Its Cultural and Social Implications," Jewish History 24, nos. 3/4 (2010): 364. 
theosophy, and so forth - was common at this time in Europe; however, a lack of faith prevailed. Zionism in the work of Herzl and Nordau represented a new kind of Jewish wandering, with a distinct humanitarian program and rejection of the religious definition of Jewishness. Its influence was vast and longstanding. The trauma of the Holocaust propelled many Jewish thinkers to insist on the creation of a land in which Jews would be legally protected. The purpose of Zionism was to end wandering and find a permanent home, where Jews would no longer be ostracized. Many have actually found true purpose in reaching this goal, even if its broad, permanent, peaceful, and unifying resolution has still remained only a hope. In effect, regardless of the founding of the State of Israel, wandering has remained the more permanent state of affairs for Jews. 